\title{
Cytological and Morphological Studies on the Gametophytes of Ferns IX The Polar Plasmolysis on Fern-prothallium (1)*
}

\author{
by Isami IGURA** \\ 伊倉伊三美：羊㐘類の配偶体に関する細胞学的並に形態学的研究 IX \\ 羊歯類前葉体の有極性原形質分離 (1)
}

\section{Received February 2, 1955}

The cyto-physiological studies on the fern-prothallia have been carried out by Gratzy-Wardengg(8) and by Reuter ${ }^{18)}$. These authors determined the osmotic values (limit concentrations of the plasmolytica) of saccharose or glucose in some species of fern-prothallia which were cultured under certain external conditions and confirmed the existence of gradients of the osmotic values in the case of prothallium. Orth ${ }^{17}$ ) made the morphological and physiological researches on the fern-prothallia but not on the plasmolyses of these prothallial cells. Besides the investigations on the prothallia, Esteřăk ${ }^{3}$ researched that the leaves of Elodea canadensis showed the "Grundgradienten" which is caused by the physical and chemical conditions and reported also in reference to the prothallium-gradient. In the Helodea-leaves fixed with $70 \%$ alcohol, Drawert ${ }^{1)}$ recognized that they revealed the existence of gradients in stainability and the correlation between the isoelectric point of the different portions of the cells and the degrees of differentiations of them. Yamaha and Negoro $\left.{ }^{23} 26\right)$ studied the osmotic phenomena on Oscillatoria princeps and reported the action of several plasmolytica on the plasmolysis. Recently, the differential plasmolysis in the eggs of Coccophola and Sargassum or the plasmolytic polarity in Cladophola was investigated by Nakazawa ${ }^{15,16)}$.

In this study the author intended to determine the existence of different osmotic value and the isotonic or the permeability coefficient also according to the portion of the adult prothallium which was not cleared by any other investigators of the fern-prothallia. With respect to the phenomenon of plasmolysis such as its form, duration, and deplasmolysis which appeared in the cells of the whole prothallium or in a single prothallial cell, new data were found, so they will be described in the following.

* a) The summary of this study was reported at the 19th annual meeting of the Botanical Society of Japan held on the 26th to 28th October, 1954 at Kyoto University. 2) The expences for the present study were partly paid by the Grant in Aid for the Micellaneous Scientific Research from the Ministry of Education.

** Biological Institute, Faculty of Education, Yamagata University 山形大学教育学部生物学教室. 


\section{Materials and Methods}

The prothallia of Pteridophyta used in the present study, were the following species belonged to Polypodiaceae: Asplenium incisum Thunberg, Leptogramma totta J. Smith, Leptorumohra Miqueliana H. Ito, and Thelypteris japonica Ching. The spores were sown on the sphagnum and a piece of unglazed pot in the Petri-dishes which were sterilized on December, 1952. These Petri-dishes were kept in the thermostat at $22^{\circ} \mathrm{C}$ and were able to receive the light normally in the room. The spores germinated in from eight days to two weeks culture and developed into the prothallia. In most cases the adnlt prothallia were used. As the plasmolytica, the following reagents were employed: nonoelectrolytes (ethyl alcohol, glucose, glycerin, saccharose, and urea) and electorolytes ( $\mathrm{AlCl}_{3}, \mathrm{CaCl}_{2}, \mathrm{KCl}, \mathrm{KNO}_{3}, \mathrm{MgCl}_{2}, \mathrm{NaCl}, \mathrm{Na}_{2} \mathrm{SO}_{4}$, $\mathrm{NH}_{4} \mathrm{Cl}, \mathrm{HCl}$, and $\mathrm{C}_{6} \mathrm{H}_{8} \mathrm{O}_{7} \cdot \mathrm{H}_{2} \mathrm{O}$ ). These reagents were applied as mol-solutions at intervals of 0.1 or $0.02 \mathrm{M}$ dissolved in the redistilled water and the solutions were reserved in the hard glass bottles. The slide- and the cover-glasses were immersed in the solution of the chrom-sulphuric acid for about twenty-four hours and washed in the running water for about the same time. The most preparations were made by the following method. The paraffin was set at the both sides of a drop of the plasmolyticum in which the prothallia were dipped and the cover-glass was put on the drop and the paraffin, and then the border of the cover-glass was sealed with

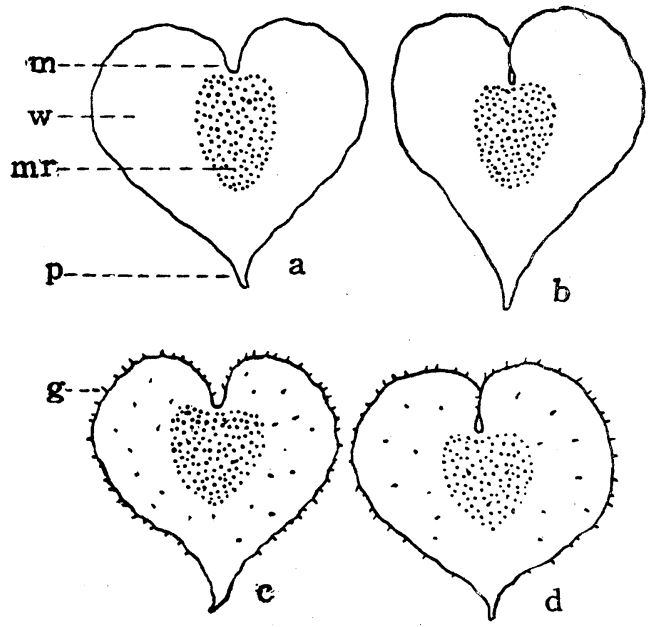

Fig. 1. The outlines of the morphological features of the adult prothallia employed in the experiment. ( $\times$ ca. 10). The prothallial cell, the archegonium, the antheridium, and the rhizoid are not shown. $m$, meristem; $\mathrm{mr}$, midrib; w, wing; g, glandular hair; p, protonema. a, Asplenium incisum Thunberg; b, Leptogramma totta J. Smith ; c, Leptorumohra Miqueliana H. Ito; d, Thelypteris japonica Ching. the paraffin. By means of this method the concentration of the plasmolyticum on the slide-glass was kept constantly for a long time during the observation. The prothallium was taken care of to prevent its injury when it was treated. Thus, the preparations were investigated under the ordinary microscope or the phase contrast one.

\section{Experimental Results}

The prothallia of four species used passed the filamentous protonema stages and developed into the heartshaped forms respectively, each of which consists of the symmetrical wings, the apical notch (meristem), the protonema, and the rhizoid, and the prothallia of Leptorumohra Miqueliana H. Ito and Thelypteris japonica Ching possess the glandular hairs (papillae) on the border and the sur- 
face of the prothallial cells here and there (Figs. $1 \mathrm{a}, \mathrm{b}, \mathrm{c}, \mathrm{d}$ ) $9,11,12,13,14,19$ ).

In this study it is considered to be pertinent to distinguish the surface area of the prothallium into several regions according to the stage of development and growth of the prothallial cells and to classify it into six regions, viz. Region I, II, III, IV, V, and VI (Fig. 2 a), though Gratzy-Wardengg8) and Reuter ${ }^{18)}$ had disting-
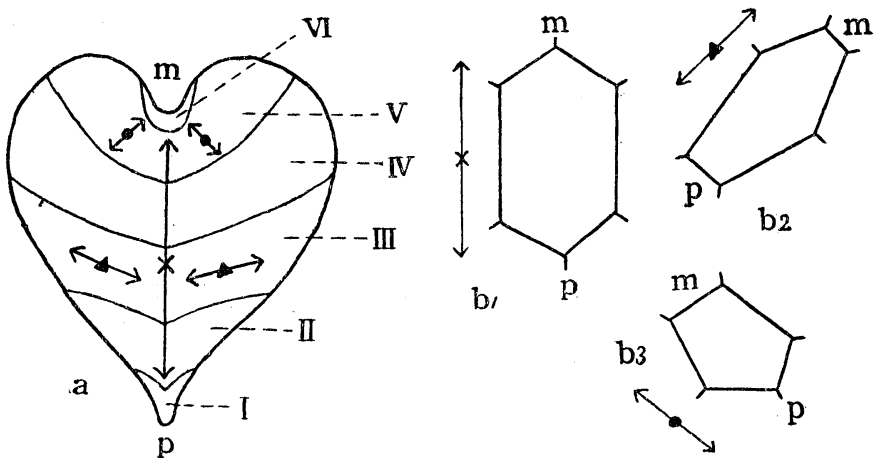

Fig. 2. The schematic views which indicate six regions and the orientations of three polarities marked with allows. a, whole surface area in the prothallium; b, single prothallial cell; $\mathrm{m}$, apical pole; $\mathrm{p}$, basal pole $; \leftarrow x \rightarrow$, longitudinal polarity $\leftrightarrow \rightarrow$, radial polarity $; \leftrightarrow \bullet \rightarrow$, tangential polarity. The lines which divided the regions were drawn generally according to the orientation of the row of the prothallial cell.

uished five zones. Moreover, the author considered the existence of the polarities in the whole prothallium or within a single cell, too. This polarity seems to be caused by the difference of the stage of development and growth of the prothallial cell and is found in the following three directions: 1) Longitudinal ("medial" of Reuter), 2) Tangential, 3) Radial. Judging from the present experiments, the author corroborated that this fact was reasonable as Reuter ${ }^{18)}$ stated. At the longitudinal polarity the author tentatively the name of a basal pole (protonema-pole) and an
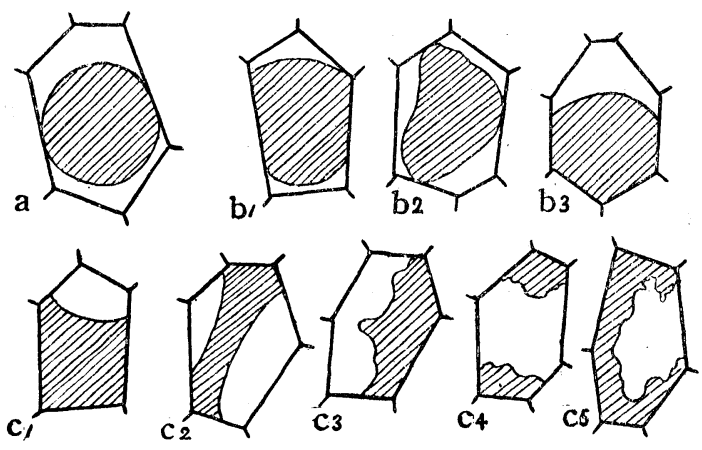

Fig. 3. The forms of plasmolysis of a single prothallial cell $(\times 250)$. To the portion of the cytoplasm the oblique lines were added. a. A-type; $b_{1}-b_{3}, B$-type; $c_{1}-c_{5}, C$-type. apical pole (meristem-pole) to the portion of the protonema and the meristem (growing point in the apical) respectively (Fig. 2 a), and the cells of the former are old, whereas those of the latter are young. In a single cell also two poles above-mentioned were considered by the author provisionally (Figs. $2 b_{1}, b_{2}, b_{3}$ ).

The forms of plasmolyses of the prothallial cells are classified into three types. The first case 
is the one which the cytoplasm shrinks in a round shape (that is, convex type), in other words, the plasmolysis gets to the maximum state and this is called A-type by the writer, secondarily, the cytoplasm separates from the membrane merely in the convex state and this is B-type, and thirdly the shrinkage of the cytoplasm is concave or irregular state and this is C-type (Fig. 3).

The experimental results will be reported in the following five contents: I) The from of plasmolysis, 2) The duration of plasmolysis (plasmolysis time), 3) The osmotic value, the isotonic and the permeability coefficient, 4) The permeabilityThe deplasmolysis, 5) Behaviour of the plastid.

\section{The form of plasmolysis}

The form of plasmolysis of the prothallial cell is different according to the region and this difference is distinct at the longitudinal polarity within the whole field of the prothallium. The extracts of the results are given in the following Table I.

Table 1. The form of plasmolysis at each region in the whole field of the prothallium

\begin{tabular}{|c|c|c|c|c|c|c|c|c|c|c|}
\hline \multirow{2}{*}{$\begin{array}{l}\text { Plasmo } \\
\text { lytica }\end{array}$} & \multirow{2}{*}{ 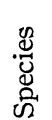 } & \multirow[b]{2}{*}{ Mol. } & \multirow{2}{*}{$\begin{array}{l}\text { Times } \\
\text { (mins.) } \\
\text { (after) }\end{array}$} & \multicolumn{6}{|c|}{ Regions } & \multirow[b]{2}{*}{ Remarks } \\
\hline & & & & I & II & III & IV & V & VI & \\
\hline \multirow{17}{*}{ 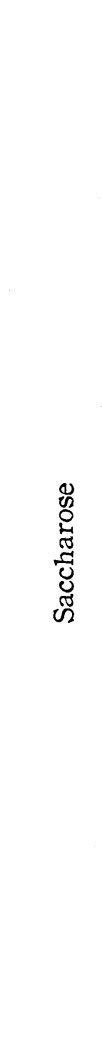 } & \multirow{3}{*}{$\mathrm{Ai}$} & 0.30 & 20 & $\pm \mathrm{B}$ & $\pm \mathrm{B}$ & $\pm \pm B$ & - & - & 一 & \multirow{3}{*}{$\mathrm{I}-27 ; 14^{\circ}, 10^{\circ} \mathrm{C}$} \\
\hline & & 0.38 & 15 & $+\mathrm{A}$ & $+\mathrm{A}$ & $\pm \mathrm{AB}$ & $\pm \pm \mathrm{B}$ & - & - & \\
\hline & & 0.82 & 90 & $+\mathrm{A}$ & $+\mathrm{A}$ & $+\mathrm{BC}$ & $+\mathrm{BC}$ & $+\mathrm{BC}$ & $+\mathrm{CB}$ & \\
\hline & \multirow{4}{*}{$\mathrm{Tj}$} & 0.32 & 8 & $\pm \pm \pm B$ & $\pm \pm \pm B$ & - & - & - & - & \multirow{4}{*}{ II- $6 ; 12^{\circ}, 7^{\prime} \mathrm{C}$} \\
\hline & & " & 30 & $\pm \mathrm{B}$ & $\pm \pm \mathrm{B}$ & - & 一 & - & 一 & \\
\hline & & 0.40 & 30 & $\pm \mathrm{B}$ & $\pm \mathrm{B}$ & \multicolumn{2}{|c|}{$\pm \pm \mathrm{B} \pm \pm \pm \mathrm{B}$} & - & 一 & \\
\hline & & 0.86 & 20 & $+\mathrm{C}$ & $+\mathrm{C}$ & $+\mathrm{CB}$ & $+B$ & $\pm \mathrm{B}$ & $\pm \pm B$ & \\
\hline & \multirow{4}{*}{$\mathrm{Lt}$} & 0.22 & 20 & - & 一 & 一 & 一 & - & - & \multirow{4}{*}{ II $-23 ; 18^{\circ} .5,12^{\circ} \mathrm{C}$} \\
\hline & & 0.34 & $5^{k}$ & $\pm \pm \pm B$ & $\pm \pm \pm B$ & - & 一 & - & - & \\
\hline & & " & 10 & $\pm \mathrm{B}$ & $\pm \mathrm{B}$ & $\pm \pm \mathrm{BC}$ & - & - & 一 & \\
\hline & & 0.58 & 20 & $+B C$ & $+\mathrm{BC}$ & $+\mathrm{BC}$ & $\pm \mathrm{BC}$ & $\pm \pm B C$ & - & \\
\hline & \multirow{6}{*}{$\mathrm{Lm}$} & 0.38 & $5^{*}$ & $\pm \pm \pm B$ & 一 & - & 一 & 一 & - & \multirow{6}{*}{ II $-16 ; 19^{\circ}, 12^{\circ} \mathrm{C}$} \\
\hline & & " & 7 & $\pm \pm B$ & $\pm \pm B$ & - & - & - & - & \\
\hline & & " & 11 & $\pm B$ & $\pm B$ & $\pm \pm B$ & 一 & - & - & \\
\hline & & " & 15 & $\pm B$ & $\pm \mathrm{B}$ & $\pm \pm B$ & $士 \pm \pm B$ & - & - & \\
\hline & & " & 30 & $+\mathrm{BA}$ & $+\mathrm{BA}$ & $\pm \mathrm{BA}$ & $\pm \pm \mathrm{BA}$ & - & - & \\
\hline & & 1.00 & 20 & $+\mathrm{BC}$ & $+B C$ & $+\mathrm{BC}$ & $\pm \mathrm{BC}$ & $\pm \mathrm{BC}$ & $\pm \pm \mathrm{BC}$ & \\
\hline
\end{tabular}




\begin{tabular}{|c|c|c|c|c|c|c|c|c|c|c|}
\hline \multirow{2}{*}{$\begin{array}{l}\text { Plasmo- } \\
\text { lytica }\end{array}$} & \multirow{2}{*}{ 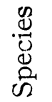 } & \multirow{2}{*}{ Mol. } & \multirow{2}{*}{$\begin{array}{c}\text { Time } \\
\text { (mins.) } \\
\text { (after) }\end{array}$} & \multicolumn{6}{|c|}{ Regions } & \multirow{2}{*}{ Remarks } \\
\hline & & & & I & II & III & IV & V & VI & \\
\hline \multirow{17}{*}{$\mathrm{CaCl}_{2}$} & \multirow{3}{*}{$\mathrm{Ai}$} & 0.30 & 3 & $+B$ & $\pm \mathrm{B}$ & $\pm \mathrm{B}$ & $\pm \pm B$ & - & - & \multirow{3}{*}{$\mathrm{II}-5 ; 17^{\circ}, 8^{\circ} .5 \mathrm{C}$} \\
\hline & & " & 10 & $+B$ & $+B$ & $+B$ & $\pm \mathrm{B}$ & - & - & \\
\hline & & " & 25 & $+\mathrm{BA}$ & $+\mathrm{BA}$ & $+B$ & $\pm \mathrm{B}$ & $\pm \pm B$ & - & \\
\hline & \multirow{5}{*}{$\mathrm{T} \mathbf{j}$} & 0.16 & 20 & $\pm \mathrm{B}$ & $\pm \mathrm{B}$ & $\pm \pm \mathrm{B}$ & - & - & - & \multirow{5}{*}{$\begin{array}{c}\mathrm{II}-13 ; 19^{\circ}, 10^{\circ} \mathrm{C} \\
\mathrm{II}-15 ; 15^{\circ}, 9^{\circ} \mathrm{C} \\
\prime \prime \\
\prime \prime \\
\prime \prime\end{array}$} \\
\hline & & 0.32 & $2^{*}$ & $+B$ & $+B$ & - & 一 & - & - & \\
\hline & & $"$ & 10 & $+B$ & $+\mathrm{B}$ & $\pm \mathrm{B}$ & $\pm \pm \mathrm{B}$ & 一 & - & \\
\hline & & " & 20 & $+B$ & $+B$ & $\pm \mathrm{B}$ & $\pm \pm B$ & $\pm \pm \pm B$ & - & \\
\hline & & $"$ & 30 & $+B$ & $+B$ & $+B$ & $\pm \mathrm{B}$ & $\pm \pm B$ & 一 & \\
\hline & \multirow{5}{*}{ Lt } & 0.12 & 10 & $\pm \pm \mathrm{B}$ & $\pm \pm \mathrm{B}$ & - & 一 & 一 & - & \multirow{5}{*}{ III- $6 ; 18^{\circ} .5,10^{\circ} \mathrm{C}$} \\
\hline & & 0.30 & $4^{*}$ & $\pm \pm \pm B$ & $\pm \pm \pm B$ & - & - & - & - & \\
\hline & & " & 10 & $+B C$ & $+\mathrm{BC}$ & $\pm \mathrm{BC}$ & $\pm \pm \mathrm{B}$ & - & - & \\
\hline & & " & 30 & $+\mathrm{BC}$ & $+\mathrm{BC}$ & $+\mathrm{BC}$ & $+\mathrm{BC}$ & $+\mathrm{BC}$ & - & \\
\hline & & 0.40 & 20 & $+\mathrm{B}$ & $+B$ & $+B$ & $\pm \mathrm{B}$ & $\pm \pm B$ & - & \\
\hline & \multirow{4}{*}{$\mathrm{Lm}$} & 0.20 & 10 & $\pm \pm \mathrm{B}$ & $\pm \pm \mathrm{B}$ & - & - & - & - & \multirow{4}{*}{ II $-20 ; 19^{\circ} .5,12^{\circ} \mathrm{C}$} \\
\hline & & " & 20 & $\pm \mathrm{B}$ & $\pm \mathrm{B}$ & $\pm \pm B$ & $\pm \pm B$ & - & - & \\
\hline & & 0.40 & $4^{*}$ & $\pm \pm B$ & $\pm \pm B$ & $\pm \pm \pm B$ & 一 & - & 一 & \\
\hline & & $" \prime$ & 15 & $+\mathrm{A}$ & $+\mathrm{A}$ & $+\mathrm{AB}$ & $\pm \mathrm{AB}$ & $\pm \pm \mathrm{B}$ & - & \\
\hline \multirow{13}{*}{ Urea } & \multirow{4}{*}{$\mathrm{Ai}$} & 0.42 & 15 & $\pm \pm B$ & $\pm \pm B$ & - & - & 一 & - & \multirow{4}{*}{$\begin{array}{c}\text { III-2; } 18^{\circ}, 14^{\circ} \mathrm{C} \\
\text { II-27; } 15^{\circ}, 11^{\circ} \mathrm{C} \\
\prime \prime \\
\prime \prime\end{array}$} \\
\hline & & 1.00 & 4 & $+B$ & $+B$ & - & 一 & - & - & \\
\hline & & " & 7 & $+B$ & $+B$ & $\pm \mathrm{B}$ & $\pm \pm B$ & - & - & \\
\hline & & " & 10 & $+\mathrm{A}$ & $+\mathrm{A}$ & $+\mathrm{AB}$ & $\pm \mathrm{AB}$ & $\pm \mathrm{BA}$ & $\pm \pm \pm B C$ & \\
\hline & \multirow{3}{*}{$\mathrm{Tj}$} & 0.30 & 15 & - & - & - & 一 & - & 一 & \multirow{3}{*}{ III- $6 ; 18^{\circ} 5,10^{\circ} \mathrm{C}$} \\
\hline & & 0.40 & 16 & $\pm \mathrm{B}$ & $\pm \mathrm{B}$ & $\pm \pm B C=$ & $\pm \pm \pm \mathrm{BC}$ & - & 一 & \\
\hline & & 0.70 & 20 & $+\mathrm{A}$ & $+\mathrm{A}$ & $+\mathrm{AB}$ & $\pm \mathrm{AB}$ & $\pm \mathrm{BA}$ & $\pm \pm \pm \mathrm{BC}$ & \\
\hline & \multirow{6}{*}{ Lt } & 0.38 & 15 & $\pm \mathrm{BC}$ & $\pm \mathrm{BC}$ & $\pm \pm \mathrm{BC}=$ & $\pm \pm \pm B C$ & - & - & \multirow{6}{*}{ III- $6 ; 18^{\circ} .5,10^{\circ} \mathrm{C}$} \\
\hline & & 0.60 & $1^{*}$ & $\pm \pm \pm B C$ & $\pm \pm \pm B C$ & 一 & 一 & - & - & \\
\hline & & $"$ & 5 & $\pm \mathrm{B}$ & $\pm \mathrm{BC}$ & $\pm \pm \mathrm{C}=$ & $\pm \pm \pm \mathrm{C}$ & - & - & \\
\hline & & $" \prime$ & 15 & $\pm \mathrm{BA}$ & $\pm \mathrm{B}$ & $\pm \mathrm{BC}$ & $\pm \pm \mathrm{BC}$ & $\pm \pm B C$ & - & \\
\hline & & $"$ & 30 & $+\mathrm{A}$ & $+\mathrm{A}$ & $+\mathrm{AB}$ & $\pm \mathrm{BC}$ & $\pm \pm \mathrm{BC}$ & - & \\
\hline & & 0.90 & 15 & $+\mathrm{BA}$ & $+\mathrm{BA}$ & $+B$ & $+\mathrm{B}$ & $\pm \mathrm{B}$ & $\pm \pm \mathrm{B}$ & \\
\hline \multirow{8}{*}{$\mathrm{KCl}$} & \multirow{5}{*}{$\mathrm{Ai}$} & 0.30 & 10 & $+B$ & $+\mathrm{B}$ & $\pm \mathrm{B}$ & $\pm B$ & $\pm \pm \mathrm{B}$ & - & \\
\hline & & " & 25 & $+B$ & $+B$ & $+B$ & $+B$ & $\pm B C$ & - & \\
\hline & & 0.40 & 0.5 & $\pm \mathrm{B}$ & $\pm \mathrm{B}$ & $\pm \mathrm{B}$ & $\pm \pm \mathrm{B}$ & - & - & III- $12 ; 9^{\circ} .5,12^{\circ} \mathrm{C}$ \\
\hline & & " & 7 & $+\mathrm{BA}$ & $+\mathrm{BA}$ & $+\mathrm{BA}$ & $\pm \mathrm{B}$ & $\pm \pm B=$ & $\pm \pm \pm B$ & \\
\hline & & 1.00 & 5 & $+\mathrm{B}$ & $+B$ & $\pm \mathrm{B}$ & $\pm \mathrm{B}$ & $\pm \pm B$ & $\pm \pm B$ & \\
\hline & & 0.18 & $9^{*}$ & $\pm \pm B$ & $\pm \pm \pm \mathrm{B}$ & - & - & - & - & \\
\hline & $\mathrm{Tj}$ & 0.26 & 10 & $\pm \mathrm{B}$ & $\pm \mathrm{B}$ & $\pm \mathrm{B}$ & $\pm \pm B$ & - & - & III- $15 ; 16^{\circ}, 11^{\circ} .5 \mathrm{C}$ \\
\hline & & 0.36 & 17 & $+\mathrm{A}$ & $+\mathrm{A}$ & $+B$ & $\pm \mathrm{B}$ & $\pm \pm B C$ & - & \\
\hline
\end{tabular}




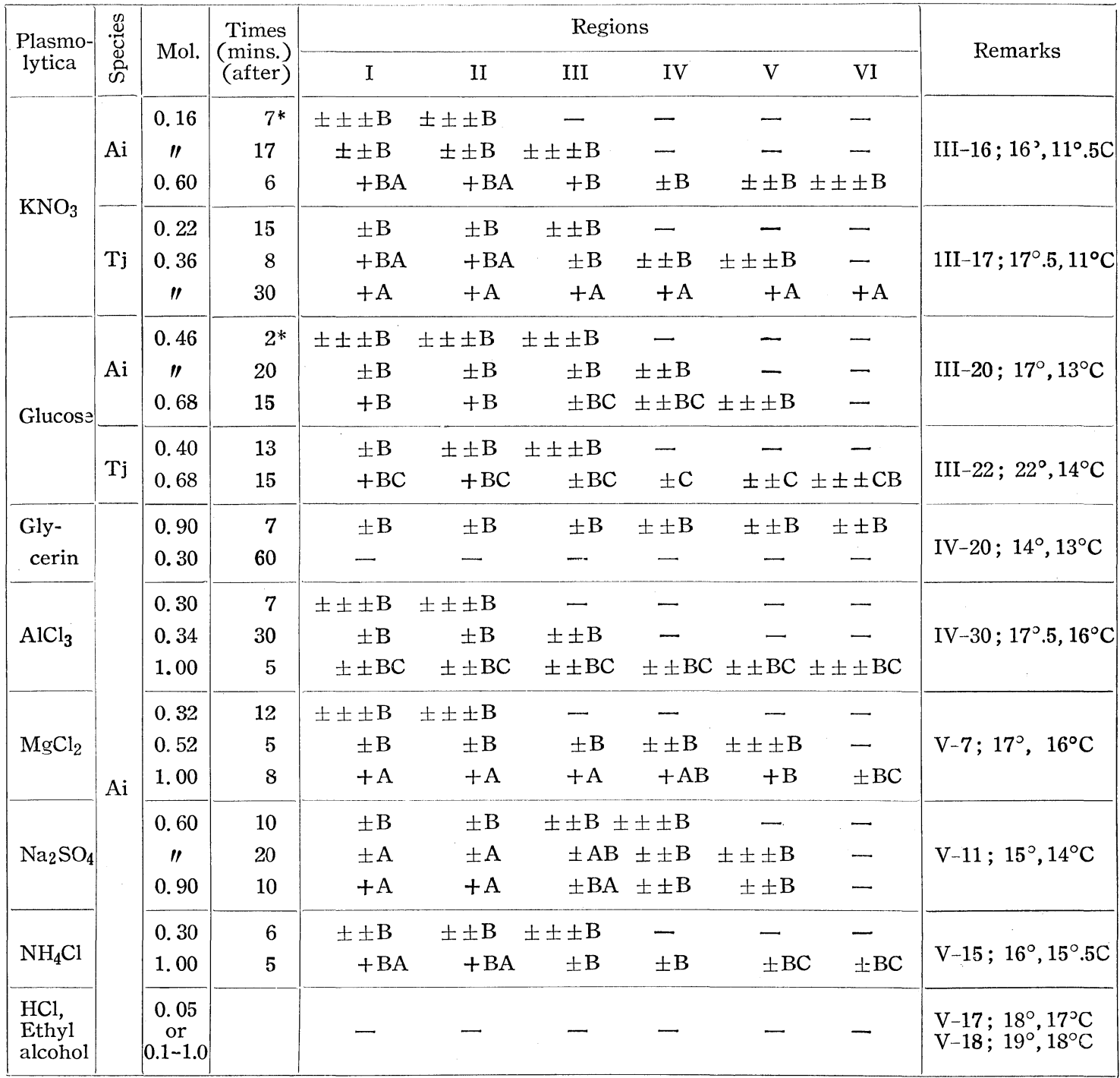

Foot-note: 1) Ai Asplenium incisum Thunberg, Tj Thelypteris japonica Ching, Lt Leptogramma totta J. Smith, Lm Leptorumohra Miqueliana H. Ito. 2) In the column of Remarks, the date, the room- and water-temperature were represented respectively, e. g. I-27 means the 27th, January. 3) Marks ,+ \pm , and - show the degrees of the plasmolysis, and + perfect or almost perfect, \pm slight, \pm \pm , \pm \pm \pm very slight, and - negative. 4) * The time when the incipient plasmolysis occurs.

(to be continued) 